\title{
FAKTOR-FAKTOR YANG MEMPENGARUHI PERSEPSI KONSUMEN PADA PENGGUNAAN ELECTRONIC PAYMENT (SERVER BASED)
}

\author{
Ajang Mandariza ${ }^{1}$, Lalu M. Furkan'2, Lalu Edy Herman Mulyono \\ ${ }^{1}$ Magister Manajemen Fakultas Ekonomi dan Bisnis, Universitas Mataram \\ E-mail: ajangmz@gmail.com \\ 2,3Fakultas Ekonomi dan Bisnis, Universitas Mataram \\ 2E-mail: lalu.furkan@gmail.com \\ 32E-mail: ehlalu@gmail.com
}

\begin{abstract}
ARTICLE INFO
Keywords :

Electronic Cash, Server Based, Ease of Use, Trust, Security, Self Efficacy, Social Influences, Usefulness, Consumer's Perception, Usage Decision.
\end{abstract}

How to cite :

Mandariza, Ajang., Furkan, Lalu M, Herman Mulyono, Edy Lalu., (2019). Faktor - Faktor Yang Mempengaruhi Persepsi Konsumen Pada Penggunaan Electronic Payment (Server Based), 8(4), 378-392

DOI :

http://dx.doi.org/10.29303/jmm.v8i4.467

Dikumpulkan : 19 Agustus 2019

Direvisi : : 20 Agustus 2019

Dipublikasi : 23 Agustus 2019

\section{ABSTRACT}

Electronic Cash (Server-Based) is one way to realize a cashless society in Indonesia. However, previous studies have shown that there are antecedents that influence consumers' perceptions of the use of electronic cash which then also influences consumer usage decisions. This study aims to look at the antecedents that affect the perception and usage decisions of Indonesian consumers regarding the use of electronic cash (server-based).The study was conducted by survey method and analyzed using the PLS approach. The results showed that ease of use, trust, security, self-efficacy, and social influences are antecedents that influence consumer perceptions and electronic cash (server-based) usage decisions.

Electronic Cash (Server-Based) menjadi salah satu cara untuk mewujudkan cashless society di Indonesia. Namun, dalam beberapa studi sebelumnya menunjukkan bahwa terdapat anteseden-anteseden yang mempemgaruhi persepsi konsumen terhadap penggunaan electronic cash yang kemudian mempengaruhi pula keputusan penggunaan (usage decision) konsumen. Penelitian ini bertujuan untuk melihat anteseden - anteseden apa saja yang mempengaruhi persepsi dan usage decision konsumen Indonesia terhadap penggunaan electronic cash (server-based). Studi dilaksanakan dengan metode survey dan dianalisa dengan pendekatan PLS. Hasil penelitian menunjukkan bahwa ease of use, trust, security, self-efficacy, dan social influences adalah anteseden-anteseden yang mempengaruhi persepsi konsumen dan keputusan penggunaan (usage decision) electronic cash (server-based).

Copyright (C) 2019 JMM UNRAM. All rights reserved. 


\title{
Jurnal Magister Manajemen Unram Vol. 8, No 4. November 2019
}

\author{
NATIONALLY ACCREDITED JOURNAL - DECREE NO. 21/E/KPT/2018
}

\section{PENDAHULUAN}

Perkembangan inovasi teknologi keuangan yang terjadi saat ini dapat menjadi peluang sekaligus ancaman, terutama pelanggan dari industri non-bank juga mengalami perubahan akibat tren inovasi teknologi keuangan ini. Digital banking menjadi salah satu bentuk nyata dari peluang yang akan dilalui oleh persaingan industri perbankan. Digital banking, baik mobile banking maupun internet banking perlahan semakin ngetren di Indonesia, sehingga digital banking merupakan masa depan perbankan dunia (Ronald Waas, Bank Indonesia, 2015). Inovasi teknologi digital tidak lagi menjadi sebuah sistem pendukung, tetapi sudah menjadi keharusan, apalagi inovasi teknologi keuangan ini akan terus memperkuat layanan perbankan di masa depan.

Indonesia merupakan negara yang menerapkan pembayaran non tunai (Cashless) yang baru dalam tahap sangat awal pada saat ini. Indonesia baru mulai menerapkan transaksi tanpa uang tunai sejak awal tahun 2010 yang disosialisasikan oleh Bank Indonesia terhadap masyarakat. Bank Indonesia mulai gencar mencanangkan program tahunan Gerakan Nasional Non Tunai (GNNT) di Jakarta sejak bulan Agustus tahun 2014. Diharapkan dengan adanya program tersebut, masyarakat Indonesia mau beralih menggunakan pembayaran non tunai tanpa uang (Cashless) dalam transaksi sehari-hari dan dapat mengurangi kebutuhan uang tunai masyarakat yang diukur dari tingkat jumlah uang yang beredar (Kompas, 2014 diakses 8 Januari 2018).

Penelitian ini bermula dari adanya riset gap dari penelitian Teoh et al. (2013), hasil penelitian menunjukkan bahwa Trust dan Security tidak berhubungan signifikan terhadap persepsi konsumen dalam menggunakan pembayaran elektronik. Berbeda dengan apa yang ditemui oleh peneliti lain, bahwa Trust dan Security menurut hasil penelitian Liao \& Wong (2008) dan Yousafzai et al. (2003), merupakan dua hal yang penting. Liao \& Wong (2008) membuktikan bahwa Security berpengaruh positif terhadap persepsi konsumen dalam menggunakan e-Banking. Lebih lagi, Yousafzai et al. (2003) membuktikan bahwa tanpa Trust dan Security, e-Banking service tidak akan berhasil.

Sejak pertama kali muncul di Indonesia pada tahun 2007 silam, penggunaan electronic money (e-money) terus meningkat. Peningkatan yang terjadi tidak hanya dalam hal jumlah pengguna namun juga bentuk dari e-money itu sendiri. Pada awal kemunculannya, e-money yang dikenal hanya e-money berupa chip based, dimana chip tersebut ditanam di media berupa kartu. Namun sekarang telah hadir juga e-money server based. E-money hadir dengan berbagai sebutan, diantaranya electronic cash (electronic Cash), digital money, digital cash, ataupun digital currency (go.ukm.id).

Semakin bertumbuhnya penggunaan electronic payment, baik card-based maupun server-based di Indonesia, kemudian membuat penulis tertarik untuk meneliti faktor-faktor apa saja yang mempengaruhi persepsi konsumen terhadap penggunaan electronic payment, dalam hal ini server-based electronic payment. Berdasarkan data statistik Bank Indonesia yang disajikan pada gambar I-1 ., penggunaan instrumen pembayaran uang elektronik (e-money) di Indonesia mengalami pertumbuhan yang positif setiap tahunnya, dapat dikatakan bahwa sistem pembayaran menggunakan instrumen e-money semakin diminati di Indonesia. Hal tersebut terbukti dari banyaknya jumlah alat pembayaran e-money yang beredar di masyarakat dimana didukung oleh dengan meningkatnya volume transaksi serta nilai transaksi penggunaan e-money yang cukup signifikan dalam lima tahun terakhir. Volume transaksi e-money pada tahun 2012 sebesar 100 juta lebih dengan nilai transaksi Rp 1.9 triliun, dan hingga akhir tahun 2015 volume transaksi sebesar 535 juta lebih dengan nilai transaksi Rp 5,2 triliun. 


\section{Jurnal Magister Manajemen Unram Vol. 8, No 4. November 2019}

NATIONALLY ACCREDITED JOURNAL - DECREE NO. 21/E/KPT/2018

Tabel I-1 Jumlah Volume dan Nilai Transaksi e-money 2012-2016

\begin{tabular}{|c|r|r|}
\hline Tahun & Volume Transaksi & Nilai Transaksi e-money \\
\hline 2012 & 100.623 .916 & $\operatorname{Rp} 1.971 .550 .000$ \\
\hline 2013 & 137.900 .779 & $\operatorname{Rp} 2.907 .432 .000$ \\
\hline 2014 & 203.369 .990 & $\operatorname{Rp} 3.319 .556 .000$ \\
\hline 2015 & 535.579 .528 & $\operatorname{Rp} 5.283 .018 .000$ \\
\hline $2016^{*}$ & 357.749 .137 & $\operatorname{Rp} 3.736 .231 .000$ \\
\hline
\end{tabular}

Sumber : Data Bank Indonesia, 2016 ( ${ }^{*}$ data triwulan 12016$)$

Antusiasme nasabah perbankan Indonesia dalam menggunakan internet banking juga terlihat pada situs Bank BCA, Bank AMZ, dan Bank BNI. Ketiga situs tersebut masuk dalam peringkat 100 top website versi alexa.com. Laporan Alexa sampai saat ini layanan internet banking pada bank BCA menduduki peringkat 12, disusul oleh bank AMZ pada peringkat 24, dan bank BNI pada peringkat 69. Peringkat akses internet banking disajikan pada tabel 1.2. berikut.

Tabel I-2 Presentase Pengguna Internet Banking Terhadap Total Nasabah tahun 2015

\begin{tabular}{|l|r|r|r|}
\hline \multicolumn{1}{|c|}{ Nama Bank } & Jumlah Nasabah & $\begin{array}{c}\text { Jumlah Pengguna } \\
\text { Internet Banking }\end{array}$ & Persentase \\
\hline BCA & 9,7 juta & 1,7 juta & $17,5 \%$ \\
\hline Bank AMZ & 11,3 juta & $783 \mathrm{ribu}$ & $6,9 \%$ \\
\hline CIMB Niaga & 2,6 juta & $205 \mathrm{ribu}$ & $7,9 \%$ \\
\hline Bank BNI & 4,7 juta & $110 \mathrm{ribu}$ & $2,3 \%$ \\
\hline
\end{tabular}

Sumber : Laporan Tahunan Kinerja Bank tahun 2014 (infobanknews.com)

Hasil dari analisa Bank AMZ terhadap potensi Branchless Banking di Indonesia, bahwa jumlah penduduk Indonesia yang belum menggunakan jasa perbankan (unbanked) masih cukup besar, layanan perbankan juga terbatas karena faktor business (cost \& benefit) \& demografi, masyarakat semakin mobile ariented terbukti cukup tingginya kepemilikan telepon genggam (hampir sama dengan jumlah penduduk diindonesia), penggunaan teknologi (telepon genggam, internet, broadband) berpotensi meningkatkan pertumbuhan ekonomi, Negara emerging market telah memanfaatkan sarana teknologi dan agen untuk menjangkau unbanked people. Sebagai upaya untuk meningkatkan pengumpulan dana masyarakat melalui peningkatan kenyamanan bertransaksi, Bank AMZ terus mengembangkan jaringan elektronik, maupun jaringan layanan lainnya. Mengikuti perkembangan zaman, Bank AMZ terus menyodorkan layanan yang serba mudah dan praktis salah satunya yang terbaru adalah AMZ electronic Cash. AMZ electronic Cash adalah uang elektronik berbasis server yang memanfaatkan teknologi aplikasi di handphone dan USSD, atau yang disebut sebagai uang tunai di handphone, dimana yang memungkinkan pemegangnya untuk melakukan transaksi perbankan tanpa harus melakukan pembukaan rekening ke cabang Bank AMZ. (electronic Cash.). Keunggulan dari produk ini terletak pada pengalaman social banking bagi pemegangnya dan merasakan kemudahan dalam penggunaannya. AMZ electronic Cash memiliki tiga karakter kemudahan yaitu: Gampang Dapat, Gampang Isi, dan Gampang Pakai.

Ini telah menjadi hal baru dalam penelitian ini. Oleh karena itu, penelitian ini bertujuan untuk mengetahui Faktor-Faktor Yang Mempengaruhi Persepsi Konsumen Pada Penggunaan Electronic Payment (Server Based)

Artikel ini terdiri dari enam bagian yang bagian pertama adalah Latar Belakang, bagian kedua adalah Tinjauan Pustaka dan Pengembangan Hipotesis yang berisi tentang Model Penerimaan Teknologi (TAM), Persepsi Konsumen, Keputusan Pembelian dan Hubungan antar variabel. Selanjutnya Metodologi, Analisis Data, Pembahasan, Kesimpulan dan Saran serta Manajerial Implikasi dan Batasan serta Penelitian selanjutnya. 


\section{Jurnal Magister Manajemen Unram Vol. 8, No 4. November 2019 NATIONALLY ACCREDITED JOURNAL - DECREE NO. 21/E/KPT/2018}

\section{TINJAUAN PUSTAKA DAN PENGEMBANGAN HIPOTESIS}

\subsection{Technology Acceptence Model (TAM)}

TAM pertama dikembangkan oleh Davis (1985) berdasarkan model Theory of Reasoned Action (TRA). Keuntungan paling penting dari TAM adalah parsimony model, yang merupakan model sederhana namun valid. Selain itu, TAM juga telah diuji dengan banyak penelitian yang hasilnya adalah model yang baik terutama jika dibandingkan dengan model TRA (Theory of Reasoned Action)) dan TPB (Theory of Planned Behavior). TAM memiliki lima konstruksi, yaitu Perceived Usefulness, Perceved ease of use, Attitude toward using technology, Behavioral Intention to use, and Actual Technology Use

\subsection{Persepsi Konsumen}

Menurut Kotler dalam Ramadhan (2013:10) menyatakan, "persepsi adalah proses yang digunakan oleh individu untuk memilih, mengorganisasi, dan menginterpretasi masukan informasi guna menciptakan gambaran yang memiliki arti". Sedangkan menurut Schiffman \& Kanuk (2008:137) dalam Permatasari (2013:20), "persepsi didefinisikan sebagai proses yang dilakukan individu untuk memilih, mengatur, dan menafsirkan stimuli ke dalam gambar yang berarti dan masuk akal mengenai dunia".

Menurut Kotler \& Keller dalam Fadila (2013:45) persepsi tidak hanya tergantung pada rangsangan dalam bentuk fisik, tetapi juga tergantung pada rangsangan yang ada disekitarnya dan kondisi yang ada pada seseorang dan persepsi lebih penting dibandingkan realitas dalam pemasaran, karena persepsi yang dapat mempengaruhi konsumen dalam berperilaku, selain itu orang bisa mempunyai persepsi yang berbeda atas objek yang sama.

Menurut Kotler (2008), orang dapat memiliki persepsi berbeda atas objek yang sama karena ada tiga proses persepsi yaitu : (1) Perhatian selektif . Pada dasarnya orang akan terlibat banyak rangsangan harian. Sebagian besar rangsangan akan disaring, karena seseorang tidak mungkin dapat menanggapi rangsangan-rangsangan ini. Proses ini disebut perhatian selektif. Perhatian selektif membuat pemasar harus bekerja keras untuk menarik perhatian konsumen. Pesan-pesan mereka akan terbuang pada orang-orang yang berada dalam pasar produk tertentu. Bahkan orang-orang yang berada dalam pasar mungkin tidak memperhatikan suatu pesan kecuali jika pesan itu menonjol dibandingkan rangsanganrangsangan lain di sekitarnya. (2) Distorsi Selektif. Distorsi selektif adalah kecenderungan orang untuk mengubah informasi kedalam pengertian pribadi dan menginterprestasikan informasi dengan cara yang akan mendukung pra-konsepsi mereka, bukannya yang menentang pra-konsepsi tersebut. Bahkan rangsangan yang telah mendapatkan perhatian konsumen, belum tentu berada di jalur yang diinginkan. (3) Ingatan Selektif. Orang akan melupakan banyak hal yang mereka pelajari, tapi karena adanya ingatan selektif, orang akan cenderung mengingat hal-hal baik yang disebutkan tentang produk pesaing.

\subsection{Keputusan Pembelian}

Menurut Salusu (2003), pengambilan keputusan adalah proses memilih alternatifalternatif bagaimana cara bertindak dengan metode efisien sesuai dengan situasi. Sedangkan Nugroho (2003:38) keputusan pembelian adalah proses pengintegrasian yang mengkombinasi sikap pengetahuan untuk mengevaluasi dua atau lebih perilaku alternatif, dan memilih salah satu diantaranya.

Menurut Suharno (2010 : 96) keputusan pembelian adalah tahap dimana pembeli telah menentukan pilihannya dan melakukan pembelian produk serta mengkonsumsinya. Pengambilan keputusan oleh konsumen untuk melakukan pembelian suatu produk diawali oleh adanya kesadaran atas kebutuhan dan keinginan, maka konsumen akan 


\section{Jurnal Magister Manajemen Unram Vol. 8, No 4. November 2019 NATIONALLY ACCREDITED JOURNAL - DECREE NO. 21/E/KPT/2018}

mencari informasi mengenai keberadaan produk yang diinginkan. Dari pendapat para ahli diatas dapat disimpulkan bahwa keputusan pembelian adalah proses memilih berbagai alternatif yang ada pada perusahaan dan sesuai dengan kepentinagnnya dalam menentukan pilihan yang sesuai dengan situasi. Berikut merupakan Tahap-tahap konsumen dalam melakukan keputusan pembelian menurut Kotler, 2005:224) yaitu :

Bagan 1-Tahap Konsumen dalam melakukan pembelian

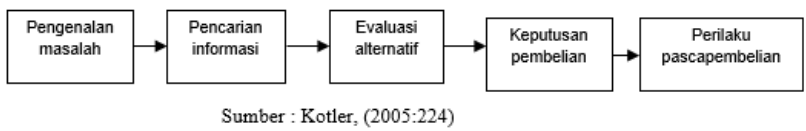

\subsection{Hubungan antara Ease of Use dan Usefulness}

Dilengkapi dengan penelitian terbaru yang mendukung Kemudahan penggunaan yang dirasakan (perceived ease of use) didefinisikan sebagai "the degree to which a person believes that using a particular system would be free of effort" (Davis 1989 dalam Suhendro, 2009). Tingkat kepercayaan seseorang bahwa penggunaan system informasi merupakan hal yang mudah dan tidak memerlukan usaha keras dari pemakainya.

Sikap pemakai sistem informasi ditentukan oleh kegunaan yang dirasakan (perceived usefulness) dan kemudahan penggunaan yang dirasakan (perceived ease of use). Pemakai akan merasakan manfaat yang lebih besar jika merasakan kemudahan dalam menggunakan sistem informasi tersebut (Suhendro, 2009). Hasil penelitian tentang perceived usefulness dan perceived ease of use sebelumnya dilakukan oleh Davis (1989), Adam et al. (1992), Davis et al. (1993) dan Horton et al. 2001 (dalam Lu et al. 2003) menunjukan adanya hubungan yang kuat variabel kemudahan penggunaan yang dirasakan (perceived ease of use) terhadap kegunaan yang dirasakan (perceived usefulness) dalam penggunaan system informasi.

H1: Ease of Use berpengaruh positif dan signifikan terhadap Usefulness

\subsection{Hubungan antara Ease of Use dan Persepsi Konsumen}

Menurut Davis (dalam Muflihhadi dan Rubiyanti, 2017) persepsi kemudahan penggunaan (Perceived Ease of Use) merupakan suatu tingkat atau keadaan dimana seseorang yakin bahwa dengan menggunakan system tertentu tidak diperlukan usaha apapun (free of effort). Selain itu menurut Jogiyanto (2007:115), persepsi kemudahan penggunaan (Perceived Ease of Use) didefinisikan sejauh mana seseorang yakin bahwa menggunakan suatu sistem teknologi akan bebas dari usaha. Dari kedua definisi tersebut dapat ditarik kesimpulan bahwa persepsi kemudahan penggunaan merupakan suatu keyakinan seseorang dalam menggunakan suatu sistem teknologi tanpa harus memerlukan usaha apapun atau bebas dari usaha.

Brown (dalam Muflihhadi dan Rubiyanti, 2017) berpendapat bahwa teknologi yang mempunyai perintah-perintah yang mudah ditemukan dan mudah dimengerti akan mempengaruhi persepsi seseorang bahwa teknologi tersebut mudah digunakan. Jika seseorang merasa percaya bahwa sistem tersebut berguna maka dia akan bereaksi positif terhadap sistem tersebut dan akan menggunakannya. Sebaliknya, jika seseorang merasa percaya bahwa sistem informasi kurang berguna maka dia tidak akan menggunakannya (Fitriana dan Wingdes, 2017).

H2 : Ease of Use berpengaruh positif signifikan terhadap Persepsi Konsumen

\subsection{Hubungan antara Securitydan Persepsi Konsumen}

Park dan Kim (2006) medefinisikan keamanan atau security sebagai kemampuan perusahaan dalam melakukan pengontrolan dan penjagaan keamanan atas transaksi data. Lebih lanjut Park dan Kim (2006) mengatakan bahwa jaminan keamanan berperan penting 


\section{Jurnal Magister Manajemen Unram Vol. 8, No 4. November 2019 NATIONALLY ACCREDITED JOURNAL - DECREE NO. 21/E/KPT/2018}

dalam pembentukan kepercayaan dengan mengurangi perhatian konsumen tentang penyalahgunaan data pribadi dan transaksi data yang mudah rusak. Ketika level jaminan keamanan dapat diterima dan bertemu dengan harapan konsumen, maka seorang konsumen mungkin akan bersedia membuka informasi pribadinya dan akan membeli dengan perasaan aman.

Jadi persepsi konsumen terhadap suatu produk (AMZ electronic Cash) akan menjadi pertimbangan konsumen dalam menentukan pilihan produk mana yang akan dibeli. Jika persepsi tersebut tinggi maka konsumen akan tertarik dan mengevaluasi masukanmasukan informasi yang mereka dapat mengenai barang (SIMAKMUR) tersebut untuk kemudian membelinya.

H3: Security berpengaruh positif dan signifikan terhadap Persepsi Konsumen

\subsection{Hubungan antara Social Influencedan Persepsi Konsumen}

Menurut Sangadji dan Sopiah (2013) social influence atau pengaruh sosial, termasuk kedalam major influence in consumer decision process. Perilaku konsumen juga akan dipengaruhi oleh masyarakat atau faktor sosial yang melingkarinya. Pengaruh sosial akan menjadi bahan pertimbangan konsumen dalam menentukan minat beli dan keputusan untuk membeli produk (Eryadi dan Yuliana, 2016).

Menurut Wang dan Chou (2014), pengaruh sosial mengacu pada bagaimana orang lain mempengaruhi keputusan perilaku seseorang. Pengaruh sosial terkait dengan tekanan eksternal (dari orang-orang penting dalam hidup seseorang, seperti keluarga, teman, dan supervisor di tempat kerja). Pengaruh sosial adalah sejauh mana jaringan sosial mempengaruhi perilaku masyarakat melalui pesan dan sinyal dari oranglain yang memfasilitasi pembentukan nilai masyarakat yang dirasakan dari sistem teknologi. Selain itu, pengaruh sosial mempengaruhi individu melalui kedua pesan tentang harapan sosial dan perilaku yang diamati dari orang lain.

H5: Social Influence berpengaruh positif dan signifikan terhadap Persepsi Konsumen

\subsection{Research Framework}

Dari penelitian dan hipotesis yang telah dijelaskan diatas, berikut merupakan kerangka konseptual

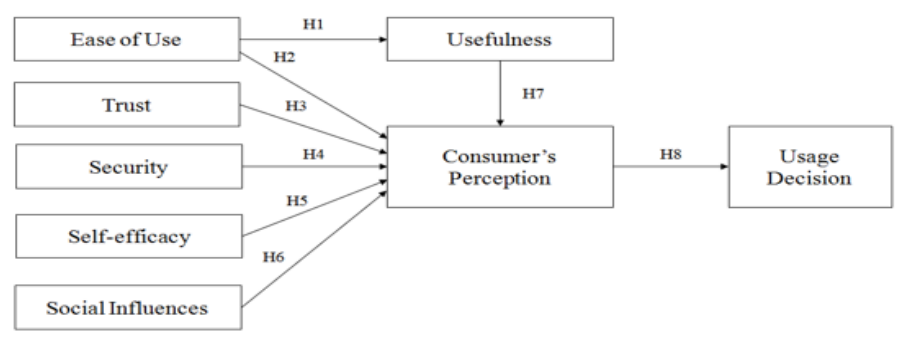

Figure 1.

Kerangka Konseptual 


\section{Jurnal Magister Manajemen Unram Vol. 8, No 4. November 2019 NATIONALLY ACCREDITED JOURNAL - DECREE NO. 21/E/KPT/2018}

\section{METODOLOGI PENELITIAN}

\subsection{Jenis Penelitian}

Jenis penelitian yang digunakan dalam penelitian ini adalah penelitian asosiatif. dengan pendekatan kuantitatif. Menurut Suliyanto (2006), penelitian asosiatif adalah penelitian yang bertujuan untuk mengetahui hubungan atau pengaruh antara dua variabel atau lebih. Populasi dalam penelitian ini adalah masyarakat yang menggunakan e-cash. Jumlah sampel yang digunakan adalah 125 responden, dengan kriteria sebagai berikut:

a. Menggunakan aplikasi e-cash kurang dari satu tahun

b. Berdomisili di pulau Nusa Tenggara Barat

\subsection{Populasi dan Sample}

Penelitian ini dilakukan dengan memberikan kuesioner secara onlinekepada 125 responden yang dijadikan sampel. Dalam penelitian ini, pengguna e-cash yang menggunakan kurang dari sama dengan satu tahun, kriterianya akan terlihat dalam deskripsi kisaran karakteristik responden. Deskripsi karakteristik responden dibagi menjadi beberapa kategori, termasuk usia responden, pekerjaan responden, domisili responden dan pendapatan bulanan responden.

Berdasarkan hasil analisis, dapat diketahui bahwa responden yang mendominasi adalah rentang usia antara 25 tahun dan 45 tahun. Usia ini dapat dianggap sebagai usia dewasa, baik wanita atau pria. Selanjutnya, untuk kategori pekerjaan, responden yang mendominasi adalah Pegawai BUMN. Domisili responden yang mendominasi adalah yang berdomisili di Mataram

\subsection{Prosedur Analisis Data}

Skala pengukuran variabel yang digunakan dalam penelitian ini adalah Skala Likert. Jawaban alternatif menggunakan skala Likert memiliki gradasi dari sangat tidak setuju ke sangat setuju yang dibuat menjadi 5 (lima) pilihan jawaban. Sementara itu, teknik analisis data menggunakan teknik Stuctural Equation Modeling (SEM) berdasarkan Partial Least Squares (PLS) menggunakan perangkat lunak SmartPLS versi 3.0. PLS adalah analisis SEM berbasis varian yang secara bersamaan dapat menguji model pengukuran dan juga dapat menguji model struktural (Abdillah \& Jogiyanto, 2009). Model pengukuran (Inner Model) digunakan untuk uji validitas dan uji reliabilitas, sedangkan model struktural (Outer Model) digunakan untuk uji kausalitas (uji hipotesis dengan model prediksi).

\subsection{Instrumen dan Pengukuran Penelitian}

Pengukuran penelitian ini menggunakan Likert (2005) yang skala mulai dari $1=$ sangat tidak setuju sampai 5 = sangat setuju. Mengenai pengujian validitas, penelitian ini menggunakan validitas konstruk dengan pengujian analisis faktor konfirmatori yang diambil dengan teknik korelasi oleh Pearson Product Moment yang menganalisis-CorrelateBivariate-Person, menggunakan two tailed dengan signifikansi $5 \%$, sedangkan $\mathrm{N}=10$, jadi $\mathrm{r}$ tabel $=0,497$. Tabel 3.4 menyajikan hasil pengujian validitas instrumen penelitian yang digunakan dalam penelitian ini. 
Table 3.4

Results of research instruments

\begin{tabular}{|c|c|c|}
\hline No. Item & R Hitung & Keterangan \\
\hline A1 & 0.653 & valid \\
\hline $\mathrm{A} 2$ & 0.687 & valid \\
\hline A3 & 0.669 & valid \\
\hline B1 & 0.675 & valid \\
\hline B2 & 0.648 & valid \\
\hline B3 & 0.692 & valid \\
\hline $\mathrm{B} 4$ & 0.832 & valid \\
\hline $\mathrm{C} 1$ & 0.698 & valid \\
\hline $\mathrm{C} 2$ & 0.860 & valid \\
\hline D1 & 0.738 & valid \\
\hline D2 & 0.801 & valid \\
\hline D3 & 0.816 & valid \\
\hline E1 & 0.728 & valid \\
\hline E2 & 0.701 & valid \\
\hline E3 & 0.865 & valid \\
\hline F1 & 0.703 & valid \\
\hline $\mathrm{F} 2$ & 0.815 & valid \\
\hline F3 & 0.722 & valid \\
\hline $\mathrm{F} 4$ & 0.728 & valid \\
\hline G1 & 0.822 & valid \\
\hline G2 & 0.903 & valid \\
\hline G3 & 0.716 & valid \\
\hline G4 & 0.805 & valid \\
\hline H1 & 0.792 & valid \\
\hline $\mathrm{H} 2$ & 0.728 & valid \\
\hline $\mathrm{H} 3$ & 0.801 & valid \\
\hline $\mathrm{H} 4$ & 0.765 & valid \\
\hline
\end{tabular}

Source : Primary Data, Processed on Mei 2017

\section{ANALISIS DATA DAN HASIL}

\subsection{Convergent Validity}

Convergent Validity untuk indikator reflektif dapat dilihat dari nilai faktor pemuatan yang disarankan yang lebih besar dari 0,70. Ini berarti bahwa korelasi antara indikator dan variabel dengan nilai loading factor lebih dari 0,70 dapat dimasukkan dalam analisis selanjutnya. Dengan penelitian pengembangan rentang pemuatan skala 0,50 - 0,60 masih dapat diterima (Imam Ghozali: 2006) Berikut ini adalah OuterModel setelah estimasi. Tabel 4.1 menyajikan tabel Convergent Validity dari Ease of Use, Trust, Security, Self Efficacy, Social Influence, Usefulness, Customer Interface, Customer Experiences..

Table 4.1

Convergent Validity

\begin{tabular}{|c|c|c|}
\hline $\begin{array}{c}\text { Kode } \\
\text { Indikator }\end{array}$ & Variabel & $\begin{array}{c}\text { Outer } \\
\text { Loading }\end{array}$ \\
\cline { 1 - 1 } A1 & \multirow{2}{*}{ Ease of Use } & 0.83529 \\
\hline A2 & & 0.60333 \\
\cline { 1 - 1 } A3 & Trust & 0.84051 \\
\hline B1 & & 0.71894 \\
\hline B2 & & 0.66248 \\
\hline
\end{tabular}




\begin{tabular}{|c|c|c|}
\hline B3 & & 0.87291 \\
\hline B4 & & 0.87022 \\
\hline $\mathrm{C} 1$ & \multirow{2}{*}{ Security } & 0.82486 \\
\hline C2 & & 0.88886 \\
\hline D1 & \multirow{3}{*}{ Self-Efficacy } & 0.88909 \\
\hline D2 & & 0.75749 \\
\hline D3 & & 0.7395 \\
\hline E1 & \multirow{3}{*}{ Social Influences } & 0.87658 \\
\hline E2 & & 0.84419 \\
\hline E3 & & 0.76771 \\
\hline F1 & \multirow{4}{*}{ Usefulness } & 0.72218 \\
\hline F2 & & 0.8882 \\
\hline F3 & & 0.77634 \\
\hline F4 & & 0.86785 \\
\hline G1 & \multirow{4}{*}{ Customer Interface } & 0.86285 \\
\hline G2 & & 0.88795 \\
\hline G3 & & 0.74794 \\
\hline G4 & & 0.87165 \\
\hline H1 & \multirow{4}{*}{ Customer Experiences } & 0.85929 \\
\hline $\mathrm{H} 2$ & & 0.74842 \\
\hline $\mathrm{H} 3$ & & 0.79072 \\
\hline $\mathrm{H} 4$ & & 0.69374 \\
\hline
\end{tabular}

Berdasarkan hasil analisis, dapat dilihat bahwa semua indikator memiliki nilai loading factor lebih dari 0,70, sehingga artinya, diterima.

Berikut ini adalah hasil dari Outer Loadingyang ditunjukkan pada Gambar 4.1

\section{Figure 4.1}

The Result of Outer Loadings after Re-Estimation

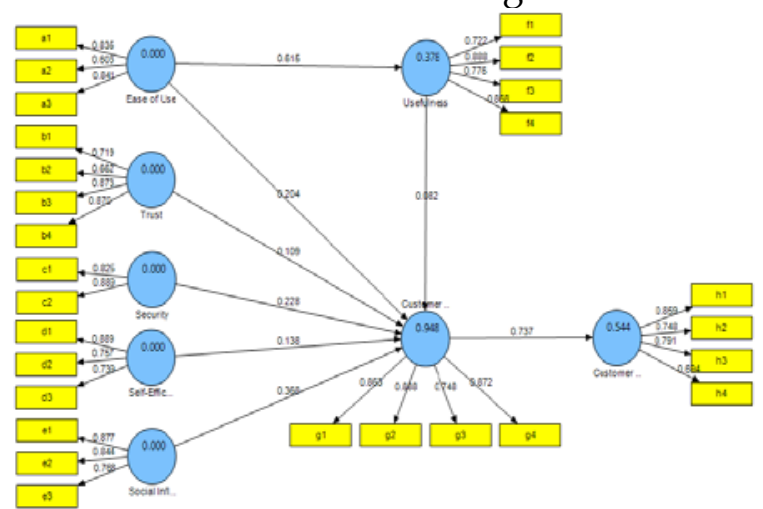

Source : Primary Data, Processed on Mei 2017

Berdasarkan gambar di atas, dapat dilihat bahwa indikator variabel memenuhi kriteria dengan nilai pembebanan luar diatas 0,70. 


\section{Jurnal Magister Manajemen Unram Vol. 8, No 4. November 2019 NATIONALLY ACCREDITED JOURNAL - DECREE NO. 21/E/KPT/2018}

\subsection{Discriminant Validity}

Discriminat validity dari model pengukuran dengan indikator refleksif dinilai berdasarkan cross loading pengukuran dengan konstruk. Jika korelasi konstruk dengan item pengukuran lebih besar daripada ukuran konstruk lainnya, maka hal itu menunjukkan bahwa konstruk laten memprediksi ukuran pada blok mereka lebih baik daripada ukuran pada blok lainnya. Cara lain mengukur discriminat validity adalah melihat nilai square root of average variance extracted (AVE). Nilai yang disarankan adalah di atas 0,5. Berikut adalah nilai AVE dalam penelitian yang dihasilkan pada Tabel

\section{Tabel 4.2}

The Square Roots Value of AVE

\begin{tabular}{|c|c|}
\hline Variabel & AVE \\
\hline Customer Experiences & 0.60126 \\
\hline Customer Interface & 0.71304 \\
\hline Ease of Use & 0.58939 \\
\hline Security & 0.73523 \\
\hline Self-Efficacy & 0.63705 \\
\hline Social Influences & 0.69014 \\
\hline Trust & 0.61875 \\
\hline Usefulness & 0.66658 \\
\hline
\end{tabular}

Source : Primary Data, Processed on Mei 2017

\subsection{Composite Reliability}

Pengujian selanjutnya adalah composite reliability dari blok indikator yang mengukur konstruk. Suatu konstruk dikatakan reliable jika nilai composite reliability di atas 0,60 (Imam Ghozali, 2006). Berikut ini hasil outer model loading yang menunjukkan composite reliabilty masing-masing konstruk pada tabel 4.3

Table 4.3

Composite Reliability

\begin{tabular}{|c|c|}
\hline Variabel & $\begin{array}{c}\text { Composite } \\
\text { Reliability }\end{array}$ \\
\hline Customer Experiences & 0.857036 \\
\hline Customer Interface & 0.908226 \\
\hline Ease of Use & 0.808313 \\
\hline Security & 0.847236 \\
\hline Self-Efficacy & 0.839454 \\
\hline Social Influences & 0.86948 \\
\hline Trust & 0.8649 \\
\hline Usefulness & 0.888168 \\
\hline Source : Primary Data, Processed on Mei 2017
\end{tabular}

\subsection{Inner Model}

Menilai inner model adalah mengevaluasi hubungan antar konstruk laten seperti yang telah dihipotesiskan dalam penelitian ini. Berikut adalah nilai R-Square pada konstruk pada tabel 4.4 


\section{Jurnal Magister Manajemen Unram Vol. 8, No 4. November 2019}

NATIONALLY ACCREDITED JOURNAL - DECREE NO. 21/E/KPT/2018

Table 4.4

$R$-Square and R-Square Adjusted

\begin{tabular}{|c|c|}
\hline Variabel & R Square \\
\hline Customer Experiences & 0.543706 \\
\hline Customer Interface & 0.947754 \\
\hline Ease of Use & \\
\hline Security & \\
\hline Self-Efficacy & \\
\hline Social Influences & \\
\hline Trust & 0.377694 \\
\hline Usefulness & \\
\hline Srimary Data Processed on Mei 2017
\end{tabular}

Source : Primary Data, Processed on Mei 2017

Tabel di atas memberikan nilai 0.543 untuk konstruk Customer Experiences, yang berarti bahwa Ease of use, security, self-efficacy, social influences, trust mampu menjelaskan varians customer experiences sebesar 54.3\%, sedangkan 55.7\% dipengaruhi oleh faktor-faktor lain. Selain itu nilai 0.947 untuk konstruk Customer Interface yang berarti bahwa Customer Interface mampu menjelaskan varians Ease of use, security, self-efficacy, social influences, trustsebesar $94.3 \%$ sedangkan sisanya sebesar 5.7\% dipengaruhi oleh faktor-faktor lain.

\subsection{Final Results}

Signifikansi parameter yang diestimasi memberikan informasi yang sangat berguna mengenai hubungan antar variable penelitian. Dasar yang digunakan dalam menguji hipotesis adalah nilai yang terdapat pada output path coefficient yaitu Original Sample, STDEV, T-Values, P-Values.Dalam PLS, pengujian secara statistic setiap hubungan yang dihipotesiskan dilakukan dengan menggunakan simulasi. Dalam hal ini dilakukan dengan metode bootsrap terhadap sampel yaitu dengan perhitungan bootstrapping untuk uji hipotesis. Pengujian dengan bootstrap ini djuga dimaksudkan duntuk meminimalkan masalah ketidaknormalan penelitian. Berikut ini adalah hasil perhitungan bootstrapping untuk pengujian hipotesis pada tabel

\section{Table 5.1}

Hasil dari Test Hipotesis

\begin{tabular}{|c|c|c|c|c|c|}
\hline Variabel & $\begin{array}{c}\text { Original } \\
\text { Sample (O) }\end{array}$ & $\begin{array}{c}\text { Sample } \\
\text { Mean (M) }\end{array}$ & $\begin{array}{c}\text { Standard } \\
\text { Deviation } \\
(\text { STDEV) }\end{array}$ & $\begin{array}{c}\text { Standard } \\
\text { Error } \\
(\text { STERR })\end{array}$ & $\begin{array}{c}\text { T Statistics } \\
(\mid \text { OSTERR } \mid)\end{array}$ \\
\hline $\begin{array}{c}\text { Customer Interface -> Customer } \\
\text { Experiences }\end{array}$ & 0.737364 & 0.746048 & 0.053639 & 0.053639 & 13.746714 \\
\hline $\begin{array}{c}\text { Ease of Use -> Customer } \\
\text { Interface }\end{array}$ & 0.203659 & 0.201804 & 0.060698 & 0.060698 & 3.35527 \\
\hline Ease of Use -> Usefulness & 0.614568 & 0.617824 & 0.066216 & 0.066216 & 9.281263 \\
\hline \begin{tabular}{c} 
Security -> Customer Interface \\
\hline $\begin{array}{c}\text { Self-Efficacy -> Customer } \\
\text { Interface }\end{array}$
\end{tabular} & 0.227506 & 0.220589 & 0.050056 & 0.050056 & 4.544991 \\
\hline $\begin{array}{c}\text { Social Influences -> Customer } \\
\text { Interface }\end{array}$ & 0.367546 & 0.364256 & 0.077175 & 0.077175 & 4.762481 \\
\hline Trust -> Customer Interface & 0.108977 & 0.108424 & 0.043282 & 0.043282 & 2.51786 \\
\hline $\begin{array}{c}\text { Usefulness -> Customer } \\
\text { Interface }\end{array}$ & 0.082285 & 0.08374 & 0.039683 & 0.039683 & 2.073548 \\
\hline
\end{tabular}




\title{
Jurnal Magister Manajemen Unram Vol. 8, No 4. November 2019
}

\author{
NATIONALLY ACCREDITED JOURNAL - DECREE NO. 21/E/KPT/2018
}

Berikut ini adalah pengujian hipotesis dalam penelitian ini.

Hipotesis 1, Hasil perhitungan software SmartPLS 2.0 menunjukkan nilai original sample sebesar 0.614568 dan T-statistics sebesar 9.281263. Nilai tersebut membuktikan bahwa Hipotesis 1 terdukung. Hasil ini berarti bahwa Ease of Use memiliki pengaruh yang positif dan signifikan terhadap usefulness. Hipotesis 2 yang menyatakan semakin baik ease of use maka akan semakin baik pula persepsi konsumen. Hasil perhitungan software SmartPLS 2.0 menunjukkan nilai original sample sebesar 0.203659 dan T-statistics sebesar 3.35527. Nilai tersebut membuktikan bahwa Hipotesis 2 terdukung. Hasil ini berarti bahwa Ease of Use memiliki pengaruh yang positif dan signifikan terhadap Customer Interface. Hipotesis 3 yang menyatakan semakin baik trust maka akan semakin baik pula persepsi konsume. Nilai perhitungan membuktikan bahwa Hipotesis 3 terdukung $(2.51781,96)$. Hasil ini berarti bahwa Trust memiliki pengaruh yang positif dan signifikan terhadap Customer Interface. Hipotesis 4 yang menyatakan semakin baik security dalam penggunaan teknologi informasi maka akan semakin baik pula persepsi konsumen. Nilai tersebut membuktikan bahwa Hipotesis 4 terdukung $(4.5449911,96)$. Hasil ini berarti bahwa Security memiliki pengaruh yang positif dan signifikan terhadap Customer Interface. Hipotesis 5 yang menyatakan semakin baik self-efficacy makaakan semakin baik pula persepsi konsumen dalam menggunakan AMZ electronic Cash.. Nilai perhitungan membuktikan bahwa Hipotesis 5 terdukung (2.01365z 1,96). Hasil ini berarti bahwa Self efficacy memiliki pengaruh yang positif dan signifikan terhadap Customer Interface.

Hipotesis 6 yang menyatakan semakinbaik social influences maka akan semakin baikpula persepsi konsumen dalam menggunakan AMZ electronic Cash. Nilai perhitungan membuktikan bahwa Hipotesis 6 terdukung $(4.762481 \geq 1,96)$. Hasil ini berarti bahwa Social Influence memiliki pengaruh yang positif dan signifikan terhadap Customer Interface. Hipotesis 7 yang menyatakan semakin baik usefulness maka akan semakin baik pula persepsi konsumen dalam menggunakan AMZ electronic Cash. Hasil perhitungan software SmartPLS 2.0 menunjukkan nilai original sample sebesar 0.082285 dan T-statistics sebesar 2.073548. Nilai tersebut membuktikan bahwa Hipotesis 7 terdukung $(2.073548$ 1,96). Hasil ini berarti bahwa Social Influence memiliki pengaruh yang positif dan signifikan terhadap Customer Interface. Hipotesis 8 yang menyatakan semakin baikpersepsi konsumen maka akan semakin baik pula keputusan menggunakan AMZ electronic Cash. Nilai perhitungan membuktikan bahwa Hipotesis 8 terdukung (13.746714 $\geq 1,96$ ). Hasil ini berarti bahwa Customer Interface memiliki pengaruh yang positif dan signifikan terhadap Customer Experience

\section{PEMBAHASAN}

Berdasarkan hasil analisis, dapat diketahui bahwa Hasil penelitian menunjukkan Ease of Use berpengaruh positif dan signifikan terhadap Usefulness. Hal ini menunjukkan bahwa semakin baik Ease of Use maka semakin baik juga Usefulness sehingga hipotesa pertama diterima. H1 Ini berarti bahwa faktor ease of use berpengaruh positif signifikan terhadap usefulness. Dengan kata lain, semakin mudah penggunaan suatu aplikasi yang ditawarkan oleh penyedia layanan akan semakin baik kegunaan yang dirasakan oleh konsumen. Sebagaimana dinyatakan oleh Suhendro (2009), pemakai akan merasakan manfaat yang lebih besar jika merasakan kemudahan dalam menggunakan sistem informasi tersebut. Hasil penelitian menunjukkan Ease of Use berpengaruh positif dan signifikan terhadap Customer Interface. Hal ini menunjukkan bahwa semakin baik Ease of Use maka semakin baik juga Customer Interface sehingga hipotesa kedua diterima. Ini berarti bahwa faktor ease of use berpengaruh positif signifikan terhadap persepsi konsumen menggunakan AMZ electronic Cash. Dengan kata lain, semakin mudah 


\title{
Jurnal Magister Manajemen Unram Vol. 8, No 4. November 2019
}

\author{
NATIONALLY ACCREDITED JOURNAL - DECREE NO. 21/E/KPT/2018
}

penggunaan suatu aplikasi yang ditawarkan oleh penyedia layanan akan semakin baik persepsi yang dirasakan oleh konsumen.

Hasil penelitian menunjukkan Trust berpengaruh positif dan signifikan terhadap Customer Interface. Hal ini menunjukkan bahwa semakin baik Trust maka semakin baik juga Customer Interface sehingga hipotesa ketiga diterima. Ini berarti bahwa faktor trust berpengaruh positif signifikan terhadap persepsi konsumen menggunakan AMZ electronic Cash. Dengan kata lain, semakin tinggi trustkonsumen terhadap aplikasi yang ditawarkan oleh penyedia layanan akan semakin baik kepercayaan yang dirasakan oleh konsumen..

Hasil penelitian menunjukkan Security berpengaruh positif dan signifikan terhadap Customer Interface. Hal ini menunjukkan bahwa semakin baik Security maka semakin baik juga Customer Interface sehingga hipotesa keempat diterima. Ini berarti bahwa faktor security berpengaruh positif signifikan terhadap persepsi konsumen menggunakan AMZ electronic Cash. Dengan kata lain, semakin tinggi rasa aman konsumen terhadap aplikasi yang ditawarkan oleh penyedia layanan akan semakin baik kepercayaan atas keamanan yang dirasakan oleh konsumen. Hasil penelitian menunjukkan Self efficacy berpengaruh positif dan signifikan terhadap Customer Interface. Hal ini menunjukkan bahwa semakin baik Self efficacy maka semakin baik juga Customer Interface sehingga hipotesa kelima diterima. Ini berarti bahwa faktor self-efficacy berpengaruh positif signifikan terhadap persepsi konsumen menggunakan AMZ electronic Cash. Dengan kata lain, semakin baik self-efficacy yang dirasakan oleh konsumen terhadap aplikasi yang ditawarkan oleh penyedia layanan akan semakin baik persepsi konsumen.

Hasil penelitian menunjukkan Social Influences berpengaruh positif dan signifikan terhadap Customer Interface. Hal ini menunjukkan bahwa semakin baik Social Influences maka semakin baik juga Customer Interface sehingga hipotesa keenam diterima. Ini berarti bahwa faktor social influences berpengaruh positif signifikan terhadap persepsi konsumen menggunakan AMZ electronic Cash. Dengan kata lain, semakin baik social influences yang dirasakan oleh konsumen akan mendorong persepsi positif yang dirasakan konsumen.

Hasil penelitian menunjukkan Usefulness berpengaruh positif dan signifikan terhadap Customer Interface. Hal ini menunjukkan bahwa semakin baik Usefulness maka semakin baik juga Customer Interface sehingga hipotesa ketujuh diterima. Ini berarti bahwa faktor usefulness berpengaruh positif signifikan terhadap persepsi konsumen menggunakan AMZ electronic Cash. Dengan kata lain, semakin baik usefulness yang dirasakan oleh konsumen akan mendorong persepsi positif yang dirasakan konsumen.

Hasil penelitian menunjukkan Customer Interface berpengaruh positif dan signifikan terhadap Customer Experiences. Hal ini menunjukkan bahwa semakin baik Customer Interface maka semakin baik juga Customer Experiences sehingga hipotesa kedelapan diterima. Ini berarti bahwa faktor persepsi konsumenberpengaruh positif signifikan terhadap keputusan konsumen menggunakan AMZ electronic Cash. Dengan kata lain, semakin baik persepsi yang dirasakan oleh konsumen akan mendorong keputusan konsumen untuk menggunakan suatu produk atau layanan.

\section{KESIMPULAN}

Sesuai dengan hasil analisis PLS dan pembahasan, maka kesimpulan yang didapat adalah :

1. Variabel Ease of Use berpengaruh positif dan signifikan terhadap usefulness sehingga hipotesis pertama pada variabel ini diterima., artinya Ease of Use memberikan andil terhadap usefulness, karena semakin baik Ease of Use maka akan semakin baik Usefulness..

2. Variabel Ease of Use berpengaruh positif terhadap Customer Interface, sehingga hipotesis kedua pada variabel ini diterima artinya Ease of Use dapat memberikan efek 


\title{
Jurnal Magister Manajemen Unram Vol. 8, No 4. November 2019
}

\author{
NATIONALLY ACCREDITED JOURNAL - DECREE NO. 21/E/KPT/2018
}

kepada Customer Interface. Customer interface atau persepsi konsumen sangatlah perlu dipupuk dari awal, istilah first impression misalnya memberikan pengaruh pada satu produk.

3. Variabel Trust berpengaruh positif terhadap Customer Interface, sehingga hipotesis ketiga pada variabel ini diterima, artinya semakin buruk trust maka akan semakin buruk juga Customer Interface. Trust atau kepercayaan yang telah diberikan konsumen hatus benar-benar dijaga melalui kualitas produk atau jasa.

4. Variabel Security berpengaruh positif dan signifikan terhadap Customer Interface, sehingga hipotesis keempat pada variabel ini diterima, artinya security atau keamanan, apalagi dalam hal ini berbicara tentang keuangan, yang sangat sensitif dan rentan untuk di hack oleh oknum-oknum tertentu, perusahaan harus membuat atau merancang security yang kompleks dan tidak mudah diretas, sehingga ini salah satu hal yang sensitif dan memberikan pengaruh pada Customer Interface.

5. Variabel Self efficacy berpengaruh positif dan signifikan terhadap Customer Interface, sehingga hipotesis kelima pada variabel ini diterima, artinya semakin baik self efficacy maka semakin baik customer interface.

\section{DAFTAR PUSTAKA}

Arvidsson, N., (2013). "Consumer attitudes on mobile payment services - results from a proof of concept test", International Journal of Bank Marketing, 32 (2): pp150-170

Ariola, M., (2006). Principles and Methods of Research. Rex book store, Inc.

Adhiputra, M.W., (2015). “Aplikasi Technology Acceptance Model Terhadap Penggunaan Layanan Internet Bangking". Jurnal Bisnis dan Komunikasi, 2 (1): pp52-63

Assauri, S. (2004). Manajemen Pemasaran. Jakarta: Rajawali Press.

Arpaci, Y.Y., Cetin., and Turetken, O., (2015). "Impact of Perceived Security on Organizational Adoption of Smartphones," Cyberpsychology, Behav. Soc. Netw., vol. 18, no. 10, pp. 602-608.

Bart, L.Y., Shankar, V., Sultan, F., and Urban, G.L., (2005). "Are the Drivers and Role of Online Trust the Same for all Web Sites and Consumers? A Large Scale Exploratory Empirical Study", International Journal Business and Managemt, pp1-49.

Baron, R. A., \& Byrne, D., (2000). Social Psychology (9th edition). Massachusetts: Allyn \&Bacon., (2004). Psikologi Sosial. Jakarta: Erlangga

Bandura, A, (2002). Self - efficacy. The exercise of control. New York: Freeman.

Benito, B., (2011). "Analisis Pengaruh Kepercayaan, Kemudahan dan Kualitas Informasi Terhadap Keputusan Pembelian Secara Online di Situs Kaskus." Semarang: Universitas Diponegoro.

Chattananon, A., Trimetsoontorn, J., (2009), "Relationship marketing: a Thai case", International Journal of Emerging Markets, 4(3): 252-274

Eryadi, H.T., dan Yuliana, E., (2016). “The Influence Of Perceived Value And Social Influence To Purchase Intention Smartphone $4 \mathrm{~g}$ In Customer Of Bandung Electronic Center", Journal Management, 3 (1): pp86-92

Fitriana, A., dan Wingdes, I., (2017). "TAM Analysis of Factors That Influence Customers to Use Indomaret Card E-Money in Pontianak", Journal Techno.COM, 16 (4): pp401-410.

Ferdinand, A. (2006). Metode Penelitian Manajemen: Pedoman Penelitian untuk skripsi, Tesis dan Disertai Ilmu Manajemen. Semarang: Universitas Diponegoro.

Ghozali, I., dan Latan, H., (2015). Partial Least Squares, Konsep, Teknik dan aplikasi Menggunakan Program SmartPLS 3.0. Untuk Penelitian Empiris. Undip.

Ghufron, M.N dan Risnawati, R., (2011). Teori-teori Psikologi. Jogyakarta: Ar-Ruzz Media. 


\title{
Jurnal Magister Manajemen Unram Vol. 8, No 4. November 2019
}

\author{
NATIONALLY ACCREDITED JOURNAL - DECREE NO. 21/E/KPT/2018
}

Handayani, R., (2007). “Analisis Faktor - Faktor yang Mempengaruhi Minat Pemanfaatan Sistem Informasi dan Penggunaan Sistem Informasi (Studi Empiris Pada Perusahaan Manufaktur di Bursa Efek Jakarta)". Jurnal Akuntansi Dan Keuangan, 9 (2): pp76-87

Jogiyanto., (2007). Sistem Informasi Keperilakuan. Yogyakarta: And

Johnson, V.L., Kiser, A., Wahington, R., and Torres, R., (2018). “Limitations to the rapid adoption of M-payment services: Understanding the impact of privacy risk on MPayment services", International Journal Elsevier, 79 : pp111-122

Kotler, P., (2005). Manajemen Pemasaran, Jilid I dan II, PT. Indeks, Jakarta

Kotler, P., dan Keller, K.L., (2008). Manajemen Pemasaran. Jilid 2. Edisi 12. Alih Bahasa Benyamin Molan. Jakarta: indeks.

Mun, Y.P., Khalid, H., and Nadarajah, D., (2017). “Millennials' Perception on Mobile Payment Services in Malaysia", International Journal Elsevier, 124 : pp397-404.

Muflihhadi, I., dan Rubiyanti, Rd. N., (2017). "Pengaruh Perceived Usefulness, Perceived Ease Of Use, Dan Trust Terhadap Kepuasan Konsumen (Studi Pada Gojek Bandung)", Jurnal Management, 3 (2): pp1-8

Nugroho, S.J., (2003), Perilaku Konsumen. Kencana. Jakarta.

Ozturk, A.B., (2015). "Customer acceptance of cashless payment systems in the hospitality industry", International Journal of Contemporary Hospitality Management, 28 (4): pp.801-817.

Rangkuti, R.R., dan Sulistyawati, E., (2013). "Pengaruh Social Influence Dan Lifestyle Terhadap Niat Membeli Pada Carrefour", Jurnal Ekonomi dan Bisnis Universitas Udayana.

Suharno, (2010). Marketing in Practice. Edisi Pertama, penerbit Graha Ilmu, Yogyakarta Sarwono, dan Sarlito W. (2009). Psikologi Sosial. Jakarta: Salemba Humanika.

Suresh, A.M., dan Shashikala R. (2011). Identifying Factors of Consumer Perceived Risk towards Online Shopping in India. IPEDR. (12): pp336-341.

Sugiyono, (2008). Metode Penelitian Kunatitatif Kualitatif dan R\&D. Bandung Alfabeta.

Tsiakis, T. and Sthephanides, G. (2005), "The concept of security and trust in electronic payments, Computers and Security, International Journal Vol. 24 No. 1, pp. 10-15.

Teoh, W.M.Y., Chong, S.C., Lin, B., and Chua, J.W., (2013). "Factors affecting consumers'perception of electronic payment: an empirical analysis", International Journal Internet Research, 23 (4): pp465-485

Wang, Edward, S.T., and Chou, Nicole, P.Y., (2014). Consumer Characteristics, Social Influence, and System Factors on Online Group-Buying Repurchasing Intention. Journal of Electronic Commerce Research, 15 (2):

Yousafzai et al. (2003). "A proposed model of e-trust for Electronic Banking", International Journal Elsevier, 23 : pp847-860

http:/ / www.beritasatu.com/ekonomi/326566-inovasi-teknologi\%20\%09tantanganperbankan-ke-depan.html-diakses desember 2017 